\title{
Correction to: A prototypical non-malignant epithelial model to study genome dynamics and concurrently monitor micro- RNAs and proteins in situ during oncogene-induced senescence
}

\author{
Eirini-Stavroula Komseli ${ }^{1 \dagger}$, Ioannis S. Pateras ${ }^{1 \dagger}$, Thorbjørn Krejsgaard ${ }^{2}$, Konrad Stawiski ${ }^{3}$, Sophia V. Rizou', \\ Alexander Polyzos ${ }^{4}$, Fani-Marlen Roumelioti ${ }^{4}$, Maria Chiourea ${ }^{4}$, loanna Mourkioti ${ }^{1}$, Eleni Paparouna', \\ Christos P. Zampetidis ${ }^{1}$, Sentiljana Gumeni ${ }^{5}$, loannis P. Trougakos ${ }^{5}$, Dafni-Eleftheria Pefani ${ }^{6}$, Eric O'Neill, \\ Sarantis Gagos ${ }^{4}$, Aristides G. Eliopoulos ${ }^{7,8}$, Wojciech Fendler ${ }^{3,9}$, Dipanjan Chowdhury ${ }^{9,10}$, Jiri Bartek ${ }^{11,12,13^{*}}$ and \\ Vassilis G. Gorgoulis ${ }^{1,4,14^{*}}$
}

\section{Correction to: BMC Genomics 19, 37 (2018) https://doi.org/10.1186/s12864-017-4375-1}

Following publication of the original article [1], it was reported that earlier versions of Table S4a and Table S4d in Additional file 11 were uploaded. The correct version of Additional file 11 has been included here, and the original article has been corrected.

\section{Supplementary Information}

The online version contains supplementary material available at https:/doi. org/10.1186/s12864-021-07608-z

Additional file 11: Table S4a. Upregulated genes in induced (ON) HBEC CDC6 Tet-ON cells. Table S4b. Down regulated genes in induced (ON) HBEC CDC6 Tet-ON cells. Table S4c. Upregulated genes in ESCA

The original article can be found online at https://doi.org/10.1186/s12864 017-4375-1.

*Correspondence: jb@cancer.dk; vgorg@med.uoa.gr

${ }^{\dagger}$ Eirini-Stavroula Komseli and loannis S. Pateras contributed equally to this work.

${ }^{11}$ Genome Integrity Unit, Danish Cancer Society Research Centre,

Strandboulevarden 49, DK-2100 Copenhagen, Denmark

1 Molecular Carcinogenesis Group, Department of Histology and Embryology, School of Medicine, National \& Kapodistrian University of Athens, 75 Mikras Asias St, GR-11527 Athens, Greece

Full list of author information is available at the end of the article
PED (ESC) HBEC CDC6 Tet-ON cells. Table S4d. Down regulated genes in ESCAPED (ESC) HBEC CDC6 Tet-ON cells.

\begin{abstract}
Author details
${ }^{1}$ Molecular Carcinogenesis Group, Department of Histology and Embryology, School of Medicine, National \& Kapodistrian University of Athens, 75 Mikras Asias St, GR-11527 Athens, Greece. ${ }^{2}$ Department of Immunology and Microbiology, University of Copenhagen, Blegdamsvej 3c, DK-2200 Copenhagen, Denmark. ${ }^{3}$ Department of Biostatistics and Translational Medicine, Medical University of Lodz, 15 Mazowiecka St., 92-215 Lodz, Poland. ${ }^{4}$ Biomedical Research Foundation of the Academy of Athens, 4 Soranou Ephessiou St., GR-11527 Athens, Greece. ${ }^{5}$ Department of Cell Biology and Biophysics, Faculty of Biology, National \& Kapodistrian University of Athens, GR-15784 Athens, Greece. ${ }^{6}$ CRUK/MRC Institute for Radiation Oncology, Department of Oncology, University of Oxford, Oxford OX3 7DQ, UK. ${ }^{7}$ Department of Biology, School of Medicine, National \& Kapodistrian University of Athens, 75 Mikras Asias St., GR-11527 Athens, Greece. ${ }^{8}$ Institute of Molecular Biology and Biotechnology, Foundation for Research \& Technology-Hellas, GR-70013 Heraklion, Crete, Greece. ${ }^{9}$ Department of Radiation Oncology, Dana-Farber Cancer Institute, 450 Brookline Ave, Boston, MA 02215, USA. ${ }^{10}$ Harvard Medical School, 25 Shattuck St, Boston, MA 02115 , USA. ${ }^{11}$ Genome Integrity Unit, Danish Cancer Society Research Centre, Strandboulevarden 49, DK-2100 Copenhagen, Denmark. ${ }^{12}$ Institute of Molecular and Translational Medicine, Faculty of Medicine and Dentistry, Palacky University, Hněvotínská, 1333/5, 77900 Olomouc, Czech Republic. ${ }^{13}$ Department of Medical Biochemistry and Biophysics, Karolinska Institute, Science for Life Laboratory, Division of Translational Medicine and Chemical Biology, SE-171 77 Stockholm, Sweden. ${ }^{14}$ Faculty of Biology, Medicine and
\end{abstract}

C C The Author(s). 2021 Open Access This article is licensed under a Creative Commons Attribution 4.0 International License, which permits use, sharing, adaptation, distribution and reproduction in any medium or format, as long as you give appropriate credit to the original author(s) and the source, provide a link to the Creative Commons licence, and indicate if changes were made. The images or other third party material in this article are included in the article's Creative Commons licence, unless indicated otherwise in a credit line to the material. If material is not included in the article's Creative Commons licence and your intended use is not permitted by statutory regulation or exceeds the permitted use, you will need to obtain permission directly from the copyright holder. To view a copy of this licence, visit http://creativecommons.org/licenses/by/4.0/ The Creative Commons Public Domain Dedication waiver (http://creativecommons.org/publicdomain/zero/1.0/) applies to the data made available in this article, unless otherwise stated in a credit line to the data. 
Health, University of Manchester, Manchester Academic Health Science Centre, Wilmslow Road, Manchester M20 4QL, UK.

Published online: 05 May 2021

\section{Reference}

1. Komseli ES, Pateras IS, Krejsgaard T, et al. A prototypical nonmalignant epithelial model to study genome dynamics and concurrently monitor micro-RNAs and proteins in situ during oncogene-induced senescence. BMC Genomics. 2018;19:37 https://doi. org/10.1186/s12864-017-4375-1. 